\title{
AN ERROR ANALYSIS ON USING PERSONAL PRONOUNS IN WRITING DESCRIPTIVE TEXT
}

\author{
Rahayu Pratiwi ${ }^{1}$, Rahma Putri Aulia ${ }^{2}$, Lilis Suryani ${ }^{3}$ \\ ${ }^{1}$ IKIP Siliwangi \\ ${ }^{2}$ IKIP Siliwangi \\ ${ }^{3}$ IKIP Siliwangi \\ ${ }^{1}$ rahayup955@gmail.com, ${ }^{2}$ rahmaputriaulia0@gmail.com, ${ }^{3}$ suryani.lies3@gmail.com
}

\begin{abstract}
The objective of this research was to know the most types of error and the most error of personal pronouns in descriptive text due to the eleventh-grade students in their descriptive paragraph writing. This research conducted qualitative research. This research was conducted at SMK Negeri 1 Cimahi in Academic Year 2018/2019. To get the data, the researchers gave an instruction for the students to make a descriptive text about person, conduct the students' writing result, read the students' writing result, identified the type of students' writing error from their text, classified the type of personal pronouns error from students' writing, and identified the high students, middle students and lower students. The sample of this research is nine students of eleventh grade from PFPT A Class (Broadcast). The result showed that there are four types of errors, they are: omission, addition, misordering, and disordering. In students' writing had been found many errors that focused on personal pronoun is 8 or $32 \%$ of omission error, 0 or $0 \%$ of addition error, 17 or $68 \%$ of mis-formation error, and 0 or $0 \%$ of disordering error. So, the highest percentage of types of error is a mis-formation error that is 17 or $68 \%$. The most error of personal pronouns in descriptive text due by the students is when they used a subject pronoun.
\end{abstract}

Keywords: Error Analysis, Personal Pronoun, Descriptive Text

\section{INTRODUCTION}

English is an International language and the most important language today. In Indonesia, English is a foreign language which studied by students as a subject in their schools. English is designed to develop knowledge and ability through four basic skills namely are listening, speaking, reading and writing. This research focuses on writing. According to Carter, et al (2002: 269) in Apsari (2017), writing is important for career and personal life because others will judge our thinking ability according to what we write and how we write it. A well-written job application letter, for example can make someone get a job or be turned away.

Blanchard and Root (1998: 1) as cited in Mundriyah and Parmawati (2016) state that learning to write in a new language is not always easy. According to Caroline (2003, p. 4) in Argawati \& Suryani (2017), writing is producing something in written form so that people can read, perform and use it. While, Meyers (2005: 2) cited in Karolina (2006) states that writing is a way to produce language you do naturally when you speak. So, writing is a form of communication that allows students to put their feelings and ideas on paper, to organize their knowledge and beliefs into convincing arguments, and to convey meaning through wellconstructed text. When we write, we have to notice on some components, such as vocabulary, spelling, pronunciation, and grammar.

According to Gebhard (1996) cited in Apsari (2018), writing involves several components which have to be considered including word choice, use of appropriate grammar, syntax, 
mechanics, and organization of ideas into coherent and cohesive form. This means that there are several aspects that need to be considered in writing. This might causes difficulties for the students. In fact, there are so many students who still lack in writing, especially in using grammar because grammar is the most difficult thing that has many rules. Zamel in Nunan (1991: 88) as cited in Parmawati (2013) states that writing skill can develop rapidly when students' concerns and interests are acknowledged, when they are given numerous opportunities to write. Harris, Ansyar, and Radjab (2012) say that it was found that students did many mistakes in using simple past tense, action verb, linking verb, and pronoun. One of aspects of English grammar that still confused by students is "personal pronoun". The personal pronoun is kind of noun determiner which is used when it is not necessary to use or repeat more exact noun phrase Swan (1995: 423) cited in Yuli (2017). While, Frank (1972: 29) in Nurjanah (2012) told, "The personal pronouns change their form for the person (First, second and third), for case (subject, object, possessive), number (singular, plural) and gender (masculine, feminine, neuter). Then, Wishon (1980: 33) in Nurjanah (2012) made a summary of the case of personal pronouns, it can be seen in the following table:

Table 1. Case of Personal Pronoun

\begin{tabular}{llll}
\hline NOMINATIVE & OBJECTIVE & POSESSIVE & POSSESSIVE \\
\hline Subject & Object & Adjective & Pronoun \\
\hline I & \multicolumn{3}{c}{ Singular } \\
\hline You & Me & My & Mine \\
\hline He & You & Your & Yours \\
\hline She & Him & His & His \\
\hline It & Her & Her & Hers \\
\hline & It & Its & - \\
\hline We & & Plural & \\
\hline You & Us & Our & Ours \\
\hline They & You & Your & Yours \\
\hline
\end{tabular}

From the table above, there are many types of personal pronouns, they are : Subject pronoun (a pronoun that functions as a subject), Object pronoun (An object pronoun is a pronoun that goes in the object position in a sentence), Possessive adjective (Possessive adjectives are followed immediately by a noun, they do not stand alone, but refer to the possessor and not to the thing possessed), and Possessive pronouns (Possessive pronouns are not followed immediately by a noun, they stand-alone. They also show possession as in possessive adjectives). In English, the usage of personal pronouns is very different from Indonesia, so it make students confused about it.

The errors in usage of personal pronoun which are made by students' especially senior high school students are able to influence the process of writing itself, so the process of writing cannot run well and the content of the text will be conveyed is not conveyed properly. Dulay et. al. (1982: 154) cited in Yuli (2017) classifies the types of errors into four types, they are omission, addition, misformation and misordering. While, Norrish (1987) in Hasyim (2002) states "...error is a systematic deviation when a learner has not to learn something and consistently gets it wrong". However, errors that are mostly made by the students should be identified, classified or described which called error analysis. Brown (2004: 218) in Yuli (2017) 
defines "error analysis is the study of students' error which can be observed, analyzed, and classified to reveal something of the system operating within the learners". So, the researchers interest to conduct this research based on the research problem: what are the most dominant errors of personal pronouns that make by students, and what are the most dominant cause of the error that make by students. It is aimed to know the most types of error and the most error of personal pronouns in descriptive text due by students and give feedback about it in order the students and teacher will get the betterment in English teaching and learning process.

In this research, the researchers would like focused on analysis personal pronouns used by students in writing descriptive text. According Corbett (1983) in Shanti, Syahrial, and Koto (2016), descriptive text is one of the expository writing. The description draws a picture, tries to convey the sound, taste, and smell of things or objects. Because in the descriptive text there is a paragraph which tells and describe person, animal, or things. It means in the descriptive text there are many use personal pronouns and change the noun or noun phrase that seems unnecessary to be used repeatedly. So, the researchers would like to analyze the use of personal pronouns by students in descriptive text.

\section{METHOD}

To complete this research, the researchers used qualitative research. Qualitative research is described as an unfolding model that occurs in a natural setting that enables the researcher to develop a level of detail from high involvement in the actual experiences (Creswell, 1994) in Williams (2007). The technique that the researchers used is descriptive analysis technique (percentage), it will be described in the following formula:

$$
\begin{aligned}
& \mathrm{P}=\frac{\mathrm{n} 1}{\sum \mathrm{n}} \times 100 \% \\
& \mathrm{P}=\text { Percentage of each error } \\
& \mathrm{n} 1=\text { Total of the given errors } \\
& \sum \mathrm{N}=\text { Total of whole errors }
\end{aligned}
$$

By calculating the frequency of each error, the researchers can identify the most frequent error and the least frequent error made by the students.

The data of the study were taken from the eleventh grade of students' PFPT A (Broadcast) in SMK Negeri 1 Cimahi. The participants who became the sample of this research consist of nine students that are from three high students, three middle students and three lower students from 36 students of PFPT A (Broadcast), that are 11 of male students and 25 of female students.

In the analyzing the data, the researchers used some steps: 1) The researchers gave an instruction for the students, that is the students should make a descriptive text about person 2) The researchers conduct the students' writing result 3) The researchers read the students' writing result 4) The researchers identified the type of students' writing error from their text 5) Classified the type of personal pronouns error from students' writing 6) The researchers identified the high students, middle students and lower students. 


\section{RESULTS AND DISCUSSION}

\section{Results}

There are four kinds of error, such as addition errors, omission errors, disordering errors and mis-formation errors. The researchers conducted the result from the students' writing of descriptive text which only focused on analyzed personal pronouns. The errors found in the students' writing is explained in the following table and description:

\section{Omission errors}

There are omission error that were found in the text, it is 8 or $32 \%$. The table below showed the results of student errors in the text.

Table 2. The Result of Omission Errors

\begin{tabular}{|c|c|c|c|}
\hline Sample & Error & It should be & $\begin{array}{c}\text { Types of Personal } \\
\text { pronoun }\end{array}$ \\
\hline Sample 1 & - & - & \\
\hline Sample 2 & - & - & \\
\hline Sample 3 & - & - & \\
\hline Sample 4 & - & - & \\
\hline Sample 5 & Has meritorious to my life & $\begin{array}{l}\text { She has meritorious to my } \\
\text { life. }\end{array}$ & Subject Pronoun \\
\hline Sample 6 & - & - & \\
\hline Sample 7 & $\begin{array}{l}\text { a. If I cry, my father } \\
\text { always } \\
\text { motivation. } \\
\text { b. And the motivation } \\
\text { him always } \\
\text { remembered in my } \\
\text { heart until now. }\end{array}$ & $\begin{array}{l}\text { a. If I cry, my father always } \\
\text { give me motivation. } \\
\text { b. And his motivation } \\
\text { always remember in my } \\
\text { heart until now. }\end{array}$ & $\begin{array}{l}\text { a. Object Pronoun } \\
\text { b. Possessive } \\
\text { Adjective } \\
\text { Pronoun }\end{array}$ \\
\hline Sample 8 & $\begin{array}{l}\text { a. She taught my class } \\
\text { with round glasses, } \\
\text { b. With affection. }\end{array}$ & $\begin{array}{l}\text { a. She teaches my class } \\
\text { with her round } \\
\text { eyeglasses, } \\
\text { b. With her affection. }\end{array}$ & $\begin{array}{l}\text { a. } \begin{array}{l}\text { Possessive } \\
\text { adjective } \\
\text { pronoun }\end{array} \\
\text { b. Possessive } \\
\text { adjective } \\
\text { pronoun }\end{array}$ \\
\hline Sample 9 & $\begin{array}{l}\text { a. He is student } \\
\text { vocational one } \\
\text { Cimahi, class twelve, } \\
\text { Department Teknik } \\
\text { Otomasi Industri. } \\
\text { b. He is very fun, he have } \\
\text { a body not realy fate, } \\
\text { have a little sharp } \\
\text { nose, } \\
\text { c. Face a little round and } \\
\text { children annoying. }\end{array}$ & 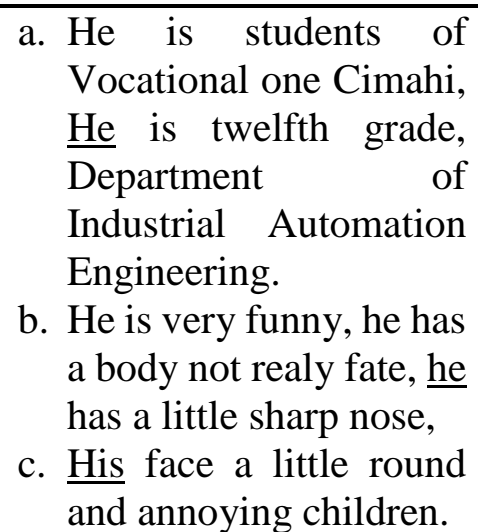 & $\begin{array}{ll}\text { a. } & \text { Subject } \\
\text { pronoun } \\
\text { b. } & \text { Subject } \\
\text { pronoun } \\
\text { c. Possessive } \\
\text { adjective } \\
\text { pronoun }\end{array}$ \\
\hline
\end{tabular}




\section{Addition error}

The table below showed the results of student errors in the text 0 or $0 \%$ of addition error.

Table 3. The Result of Addition Error

\begin{tabular}{llll}
\hline Sample & Error & It should be & $\begin{array}{c}\text { Types of Personal } \\
\text { Pronoun }\end{array}$ \\
\hline Sample 1 & - & - & \\
\hline Sample 2 & - & - & \\
\hline Sample 3 & - & - \\
\hline Sample 4 & - & - \\
\hline Sample 5 & - & - \\
\hline Sample 6 & - & - \\
\hline Sample 7 & - & - \\
\hline Sample 8 & - & - \\
\hline Sample 9 & - & \\
\hline
\end{tabular}

\section{Mis-formation}

There are omission error that were found in the text, it is 17 or $68 \%$. The table below showed the results of student errors in the text.

Table 4. The Result of Mis-Formation

\begin{tabular}{|c|c|c|c|}
\hline Sample & Error & It should be & $\begin{array}{c}\text { Types of Personal } \\
\text { Pronoun }\end{array}$ \\
\hline Sample 1 & $\begin{array}{l}\text { He's name is Andi, we } \\
\text { have same age. }\end{array}$ & $\begin{array}{l}\text { His name is Andi, we have } \\
\text { same age. }\end{array}$ & $\begin{array}{l}\text { Possessive } \\
\text { adjective pronoun }\end{array}$ \\
\hline Sample 2 & $\begin{array}{l}\text { I wondered, my father } \\
\text { and my family feel so } \\
\text { lucky to have you. }\end{array}$ & $\begin{array}{l}\text { I wondered, my father and } \\
\text { my family feel so lucky to } \\
\text { have her. }\end{array}$ & $\begin{array}{l}\text { Possessive } \\
\text { adjective pronoun }\end{array}$ \\
\hline Sample 3 & $\begin{array}{l}\text { He has big boddy like } \\
\text { doraemon because he eat } \\
\text { a lot and rarely playing } \\
\text { with him friends. }\end{array}$ & $\begin{array}{l}\text { He has bid body like } \\
\text { doraemon because he eat } \\
\text { so much and rarely play } \\
\text { with his friends. }\end{array}$ & $\begin{array}{l}\text { Possessive } \\
\text { adjective pronoun }\end{array}$ \\
\hline Sample 4 & $\begin{array}{l}\text { a. Her was } 21^{\text {st }} \text { years } \\
\text { old. } \\
\text { b. Good dracule suitable } \\
\text { for her nickname } \\
\text { because her praise was } \\
\text { good, but her have a } \\
\text { bad emotional. } \\
\text { c. One day, in Sunday } \\
\text { morning, her wake up } \\
\text { early morning than } \\
\text { me, } \\
\text { d. sudenly her angry } \\
\text { while patting my back } \\
\text { and said "Bangun }\end{array}$ & $\begin{array}{l}\text { a. She is } 21^{\text {st }} \text { years old. } \\
\text { b. Good dracule suitable } \\
\text { for her nickname } \\
\text { because her praise is } \\
\text { good, but she has a bad } \\
\text { emotional. } \\
\text { c. One day, in Sunday } \\
\text { morning, she wake up } \\
\text { early morning than me, } \\
\text { d. suddenly she angry } \\
\text { while patting my back } \\
\text { and said "Bangun atuh! } \\
\text { Tidur wae" (with angry } \\
\text { intonation) }\end{array}$ & $\begin{array}{l}\text { a. Subject pronoun } \\
\text { b. Subject pronoun } \\
\text { c. Subject pronoun } \\
\text { d. Subject pronoun } \\
\text { e. Subject pronoun } \\
\text { f. Subject pronoun } \\
\text { g. Subject pronoun }\end{array}$ \\
\hline
\end{tabular}




\begin{tabular}{|c|c|c|c|}
\hline & $\begin{array}{l}\text { atuh! Tidur wae" } \\
\text { (with angry intonasi). } \\
\text { e. But her choose for go } \\
\text { while angry. } \\
\text { f. During Sunday her } \\
\text { was angry no reason. } \\
\text { g. Her patting my back } \\
\text { again and said for } \\
\text { accompany her to } \\
\text { toilet. }\end{array}$ & $\begin{array}{l}\text { e. But, she choose to go } \\
\text { while angry. } \\
\text { f. During Sunday she was } \\
\text { angry no reason. } \\
\text { g. She patting my back } \\
\text { again and said for } \\
\text { accompany her to go to } \\
\text { toilet. }\end{array}$ & \\
\hline Sample 5 & $\begin{array}{l}\text { Because, she is my } \\
\text { mother. She name's } \\
\text { Sumaroh "Angel in my } \\
\text { life". }\end{array}$ & $\begin{array}{l}\text { Because, she is my } \\
\text { mother. Her name is } \\
\text { Sumaroh, "Angel in my } \\
\text { life" }\end{array}$ & $\begin{array}{l}\text { Possessive } \\
\text { adjective pronoun }\end{array}$ \\
\hline Sample 6 & $\begin{array}{l}\text { Now, she is work in a } \\
\text { hospital. I'm very love } \\
\text { him because she is the } \\
\text { only one of my sister. }\end{array}$ & $\begin{array}{l}\text { Now, she is work in a } \\
\text { hospital. I'm very love her } \\
\text { because she is the only one } \\
\text { of my sister. }\end{array}$ & Object pronoun \\
\hline Sample 7 & $\begin{array}{l}\text { a. My father always said, } \\
\text { "If I grow up, } \\
\text { b. I should be able to be } \\
\text { the presence of very } \\
\text { waiting by the family, } \\
\text { the child who is very } \\
\text { useful. } \\
\text { c. My education to } \\
\text { higher him" }\end{array}$ & $\begin{array}{l}\text { a. My father always said, } \\
\text { "If you grow up, } \\
\text { b. you should be able to } \\
\text { be the presence which } \\
\text { very waited by the } \\
\text { family, the child who is } \\
\text { very useful. } \\
\text { c. Your education should } \\
\text { be higher than me". }\end{array}$ & $\begin{array}{l}\text { a. Subject pronoun } \\
\text { b. Subject pronoun } \\
\text { c. Possessive } \\
\text { adjective } \\
\text { pronoun }\end{array}$ \\
\hline Sample 8 & $\begin{array}{l}\text { a. I wish she achieved } \\
\text { his dream in the health } \\
\text { sector. } \\
\text { b. And if we meet one } \\
\text { day after the same } \\
\text { success, he still } \\
\text { remembers me. }\end{array}$ & $\begin{array}{l}\text { a. I wish she achieved her } \\
\text { dream in the health } \\
\text { sector. } \\
\text { b. And if we meet one day } \\
\text { after the same success, } \\
\text { she still remember of } \\
\text { me. }\end{array}$ & $\begin{array}{l}\text { a. Possessive } \\
\text { adjective } \\
\text { pronoun } \\
\text { b. Subject pronoun }\end{array}$ \\
\hline
\end{tabular}

Sample 9

\section{Disordering error}

The table below showed the results of student errors in the text 0 or $0 \%$ of addition error.

Table 5. The Result of Disordering Error

\begin{tabular}{lccc}
\hline Sample & Error & It should be & $\begin{array}{c}\text { Type of Personal } \\
\text { pronoun }\end{array}$ \\
\hline Sample 1 & - & - & \\
\hline Sample 2 & - & - & \\
\hline Sample 3 & - & - & \\
\hline Sample 4 & - & - & \\
\hline Sample 5 & - & - & \\
\hline
\end{tabular}




\begin{tabular}{lll}
\hline Sample 6 & - & - \\
\hline Sample 7 & - & - \\
\hline Sample 8 & - & - \\
\hline Sample 9 & - & - \\
\hline
\end{tabular}

\section{Discussion}

From the result above, the researchers can conclude :

Table 6. The Data Tabulation

\begin{tabular}{lcc}
\hline \multicolumn{1}{c}{ Category } & Frequency & Percentage \\
\hline $\begin{array}{l}\text { Omission Error of Personal } \\
\text { Pronoun }\end{array}$ & 8 & $32 \%$ \\
\hline $\begin{array}{l}\text { Addition Error of Personal } \\
\text { Pronoun }\end{array}$ & 0 & $0 \%$ \\
\hline $\begin{array}{l}\text { Mis-formation Error of } \\
\text { Personal Pronoun }\end{array}$ & 17 & $68 \%$ \\
\hline $\begin{array}{l}\text { Disordering Error of } \\
\text { Personal Pronoun }\end{array}$ & 0 & $0 \%$ \\
\hline
\end{tabular}

From the data tabulation above, the researchers concluded that the errors made by eleventhgrade students at SMKN 1 Cimahi, the errors are classified into four types of error based on surface strategy. The first is omission error the errors made by the students is 8 errors or $32 \%$, the second is mis-formation error which made by the students is 17 errors or $68 \%$. It is supported by Wijayanto (2013), "the types of error which made by the students were mostly misformation error, and the cause of error which most occurred was incomplete application of rule". But in this research, for addition error and disordering error, the students did not make an error.

From the data of the research above, it can be concluded that the most of errors that made by eleventh-grade students of SMK Negeri 1 Cimahi is Mis-formation which is the errors 17 of errors or $68 \%$ from total errors made.

\section{CONCLUSION}

There are two types of errors made by eleventh-grade students of SMK Negeri 1 Cimahi academic year 2018/2019 on using a personal pronoun in writing descriptive text, those errors are Omission of subject (she, he), omission of object (me), omission of possessive adjective (his, her). Mis-formation of subject (She, you), mis-formation of Possessive adjective (his, her, your), mis-formation of object (her). So, from result above the writer can conclude that the most types of personal pronoun error is when they are using subject pronoun, the highest percentage of the frequent error types that made by eleventh-grade students found that mis-formation errors were up to $68 \%$.

\section{ACKNOWLEDGMENTS}

Alhamdulillah all gratitude to Allah S.W.T who gave His blessing to researchers, so researchers can finish this article with a good health condition. Researchers would like to say the biggest thank you for researchers' article supervisors who always gave researchers support when 
conducting this research. Also, researchers would like to say thank you to IKIP Siliwangi Bandung which gave us the opportunity to publish this article. Also for a blind reviewer who reviewed this article as well as to the editorial team so this article can be published perfectly.

\section{REFERENCES}

Apsari, Y. (2017). The Use Of Picture Series In Teaching Writing Recount Text. Eltin Journal, Journal Of English Language Teaching In Indonesia, 5(2), 51-56.

Apsari, Y. (2018). Reflective Reading Journal in Teaching Writing. Indonesian EFL Journal, $4(2), 39$.

Argawati, N. O., \& Suryani, L. (2017). Teaching Writing Using Think-Pair-Share Viewed From Students' Level of Risk-Taking. ERJEE, 6(1), 109-116. https://doi.org/10.25134/erjee.v6i1.776.Received

Harris, A., Ansyar, M., \& Radjab, D. (2012). An Analysis of Students' Difficulties in Writing Recount Text at Tenth Grade of SMA N 1 Sungai Limau. Journal English Language Teaching (ELT), 2(1), 1-50.

Hasyim, S. (2002). Error Analysis in the Teaching of English. 4(1), 62-74. Retrieved from http://puslit2.petra.ac.id/ejournal/index.php/ing/article/view/15485

Karolina, I. (2006). Teaching Narrative Text in Improving Writing To the Ten Th. 74. Retrieved from http://lib.unnes.ac.id/1180/1/2081.pdf

Mundriyah, M., \& Parmawati, A. (2016). Using Think-Pair-Share (Tps) To Improve Students'writing Creativity (A Classroom Action Research In The Second Semester Students Of Stkip Siliwangi Bandung). P2m Stkip Siliwangi, 3(2), 84-91.

Nurjanah. (2012). Analysis of Students' Error in Using Personal Pronouns. 4(2), 141-158.

Parmawati, A. (2013). The efffectiveness of Think-Pair-Share (TPS) to Teach Writing Viewed From Students Creativity (Doctoral dissertation, SEBELAS MARET UNIVERSITY).

Shanti, V. M., Syahrial, \& Koto, I. (2016). Project Based Learning Approach to Improve Students' Ability to Write Descriptive Text (A Classroom Action Research at Grade X SMAN I Bengkulu Selatan). JOALL (Journal of Applied Linguistics and Literature), 2(2), 46-54. https://doi.org/10.33369/joall.v1i2.4196

Wijayanto, A. (2013). Error Analysis in the Use of Personal Pronouns Made by Eleventh Graders in Writing. 1-6.

Williams, C. (2007). Research methods. Journal of Business \& Economic Research, 5(3), 8182. https://doi.org/10.1007/978-3-319-10906-0_5

Yuli, A. M. S. (2017). An Error Analysis on Using Personal Pronouns in Writing Recount Paragraph Made By the Eighth Grade Students of Smp Negeri 1 Prambon. Artikel Skripsi Universitas Nusantara PGRI Kediri. 